\title{
Acute Myeloid Leukemia, E-coli bacteremia, Salmonella urinary tract infection, Clostridium Difficile colitis, Subarachnoid hemorrhage and Gastrointestinal bleeding in an HCV Cirrhotic Patient on newly approved Anti-HCV Medications
}

\author{
Habeeb Salameh ${ }^{1}$, Hamzeh Saraireh ${ }^{2}$, Shehzad Merwat ${ }^{1}$ \\ ${ }^{1}$ Department of Gastroenterology and Hepatology, University of Texas Medical Branch, Texas. \\ ${ }^{2}$ Department of Internal medicine, University of Texas Medical Branch, Texas
}

Submission: November 11, 2016; Published: January 20, 2016

*Corresponding author: Habeeb Salameh, Division of Gastroenterology \& Hepatology, University of Texas Medical Branch, Galveston, Texas,

Tel: 409-772-1501; Email: Habeeb.salameh@yahoo.com

\section{Introduction}

Chronic HCV infection can predispose to different lymphoproliferative disorders including lymphomas (diffuse large B-cell lymphoma, marginal zone lymphoma, lymphoplasmacytic lymphoma) and plasma cell disorders (monocolonalgammopathies) [1,2]. Kelaidi et al reported a case of large granular lymphocyte leukemia occurring in association with Marginal Zone Lymphoma and HCV and responding to interferon and ribavirin [3]. They have suggested an etiologic link between HCV and antigen-driven lymphoproliferative disorders [3].

A large retrospective cohort study (HCV-infected cohort = 1,46,394; HCV-non-infected cohort $=5,72,293$ ), among US veterans showed significant association between HCV infection and non-Hodgkin's Lymphoma (NHL), Waldenstrom's Macroglobulinemia (WM) and cryoglobulinemia but failed to show any association with Hodgkin's lymphoma (HD) or multiple myeloma (MM), chronic lymphocytic leukemia (CLL), acute lymphocytic leukemia (ALL), acute myeloid leukemia (AML) and chronic myeloid leukemia (CML) [4]. One other study from Hematology departments from ten different Italian cities, the prevalence of HCV infection was higher in patients with CLL $(9.0 \%, 9$ out of 100$)$, ALL $(7.6 \%, 5$ out of 54$)$, AML $(7.9 \%, 11$ out of 140$)$, and CML $(12.2 \%, 6$ out of 49$)$ patients. These patient groups were not, however, large enough to render statistically significant results [5]. In one study from the association between HCV infection and AML/ALL/refractory anemia with excess blast was found to be weak and statistically non-significant [6].
Recently the Ledipasvir-Sofosbuvir combination has been approved for treating chronic HCV infection, genotype 1 in both cirrhotic and non-cirrhotic patients [7]. The most common reported adverse events were fatigue, headache, insomnia, and nausea [8]. Documented life threatening complications of the combination medicine includes symptomatic bradycardia especially with concurrent use of amiodarone [9]

\section{Case presentation}

We report a 47-year-old male with EtOH/HCV cirrhosis -MELD score 17-, treatment naïve who was started on the combination Ledipasvir-Sofosbuvir on September, 1st, 2015. His baseline blood work was suggestive of pancytopenia mostly secondary to hypersplenism (Table 1). He presented to our hospital ten weeks later with coffee ground emesis, delirium, and hypoxic respiratory failure requiring intubation and mechanical ventilation. Esophagogastroduodenoscopy (EGD) showed nonbleeding gastric varix and portal hypertensive gastropathy with no obvious source of bleeding. MCi Tc-99m Ultratag RBC scan was negative as well. Blood work showed worsening pancytopenia (Table 1), metabolic acidosis and elevated ammonia level. An automated white blood cell differential was not done due to leucopenia. Manual counts showed 70\% Neutrophils and $30 \%$ lymphocytes. He was given two doses of Granulocyte-Colony Stimulating Factor (G-CSF). Three days later he developed disseminated intravascular coagulation (DIC) with a coagulation panel showing a prothrombin time PT of 35, INR 3.5 , fibrinogen less than 60 , D-dimer more than 20 and FDP more 
than 20. Blood cultures were positive for E-coli bacteremia, stool positive for Clostridiumdifficile and urine culture was positive for Salmonella infection.

Patient was treated with appropriate antimicrobial regimens and blood products. Meanwhile a computed tomographic imaging of head was done due to patient's inability to follow commands while still intubated and off sedation. It showed left frontal and temporal subarachnoid hemorrhage. His blood counts showed sudden rise in WBC, with peripheral blood smear showing 85\% abnormal leucocytes with high suspicion for Acute Promyeloid Leukemia(APML). Phenotyping by flow cytometry showed peripheral blood with high population of CD117 positive, CD34 negative, HLA-DR negative myeloblasts representing approximately 93\% of leucocytes consistent with Acute Myeloid Leukemia (AML). Subsequently he was started on All-TransRetinoic Acid (ATRA) and Arsenic trioxide. He initially recovered from gram-negative bacteremia, urinary tract infection and intra-cranial bleeding. He was transferred out of the intensive care unit eleven days after admission. He continued his clinical recovery till day eighteen of hospitalization when he complained of abdominal pain and developed hypotension, tachypnea and hypoxia. Acute abdominal series failed to reveal air under diaphragm and any evidence of mega colon. He was transferred back to the intensive care unit and his condition deteriorated rapidly. He had severe lactic acidosis with an arterial PH of 6.8 and eventually cardiac arrest. Resuscitation was unsuccessful and he was pronounced on day eighteen of hospitalization. Autopsy was not done per family request.

We as gastroenterologists, hepatologists and internists should not presume that pancytopenia is solely a manifestation of hypersplenism especially when there is a significant drop in blood counts compared to previous values. Most probably his leukemia and blasts were hiding in the bone marrow and G-CSF subsequently revealed it in the peripheral blood. Finally, we cannot make any conclusions or even suggestions of possible association between chronic HCV infection and leukemia -AML in this case- from one side or between new directly acting antivirals and leukemia from this case but we aim to report this unusual co-incidence.

Table 1: Laboratory results.

\begin{tabular}{|c|c|c|c|}
\hline & $\begin{array}{c}\text { 6 months before } \\
\text { HCV treatment }\end{array}$ & $\begin{array}{c}\text { 70 days after start } \\
\text { of HCV treatment }\end{array}$ & $\begin{array}{c}\text { 10 Days after } \\
\text { APL treatment }\end{array}$ \\
\hline HGB & 13.4 & 8.7 & 7.7 \\
\hline WBC & 7.7 & 0.8 & 8.8 \\
\hline Platelets & 92 & 23 & 40 \\
\hline HCV PCR & 31,270 & Undetectable & NR \\
\hline
\end{tabular}

\section{Author Contributions}

$\mathrm{H}$ Salameh and $\mathrm{H}$ Saraireh wrote the manuscript and reviewed the literature. $\mathrm{H}$ Salameh and S Merwat critically revised the manuscript for important intellectual content, supervised the process and approved the final draft. H Salameh is the article guarantor and the corresponding author.

Financial disclosure: None to report

\section{Conflict of Interest: None to report}

\section{Reference}

1. Idilman R, Colantoni A, De Maria N, Alkan S, Nand S, et al. ( 2004) Lymphoproliferative disorders in chronic hepatitis C. J Viral Hepat 11(4): 302-309.

2. Mollejo M, Menárguez J, Guisado-Vasco P, Bento L, Algara P et al. (2014) Hepatitis C virus-related lymphoproliferative disorders encompass a broader clinical and morphological spectrum than previously recognized: a clinicopathological study. Mod Pathol 27(2): 281-293.

3. Kelaidi C, Rollot F, Park S, Tulliez M, Christoforov B, et al. (2004) Response to antiviral treatment in hepatitis $\mathrm{C}$ virus-associated marginal zone lymphomas. Leukemia 18(10): 1711-1716.

4. Giordano TP, Henderson L, Landgren O, Chiao EY, Kramer JR, et al. (2007) Risk of non-Hodgkin lymphoma and lymphoproliferative precursor diseases in US veterans with hepatitis C virus. JAMA 297(18):2010-2017.

5. Bianco E, Marcucci F, Mele A, Musto P, Cotichini R, et al. (2004) Prevalence of hepatitis $\mathrm{C}$ virus infection in lymphoproliferative diseases other than B-cell non-Hodgkin's lymphoma, and in myeloproliferative diseases: an Italian Multi-Center case-control study. Haematologica 89(1): 70-76.

6. Gentile G, Mele A, Monarco B, Vitale A, Pulsoni A, et al. (1996) Hepatitis $B$ and $C$ viruses, human T-cell lymphotropic virus types I and II, and leukemias: a case-control study. The Italian Leukemia Study Group. Cancer Epidemiol Biomarkers Prev. 5(3): 227-230.

7. Panel AIHG (2015) Hepatitis C guidance: AASLD-IDSA recommendations for testing, managing, and treating adults infected with hepatitis C virus. Hepatology 62(3): 932-954.

8. Afdhal N, Zeuzem S, Kwo P, Chojkier M, Gitlin N, et al. (2014) Ledipasvir and sofosbuvir for untreated HCV genotype 1 infection. N Engl J Med 370(20): 1889-1898.

9. Fazel Y, Lam B, Golabi P, Younossi Z (2015) Safety analysis of sofosbuvir and ledipasvir for treating hepatitis C. Expert Opin Drug Saf 14(8):1317-1326. 
Your next submission with Juniper Publishers will reach you the below assets

- Quality Editorial service

- Swift Peer Review

- Reprints availability

- E-prints Service

- Manuscript Podcast for convenient understanding

- Global attainment for your research

- Manuscript accessibility in different formats

( Pdf, E-pub, Full Text, Audio)

- Unceasing customer service

Track the below URL for one-step submission https://juniperpublishers.com/online-submission.php 